\title{
PARENTS' VIEWS ON LEARNING FOREIGN LANGUAGES IN SCHOOL
}

\author{
PhD Maria-Gabriela Drăghici *1 ${ }^{*}$ (iD \\ ${ }^{* 1}$ Education Sciences; University of Bucharest, Faculty of Psychology and Education Sciences, \\ Bucharest
}

DOI: https://doi.org/10.29121/granthaalayah.v8.i8.2020.1004

Article Type: Research Article

Article Citation: PhD Maria-

Gabriela Drăghici. (2020).

PARENTS' VIEWS ON LEARNING

FOREIGN LANGUAGES IN SCHOOL.

International Journal of Research -

GRANTHAALAYAH, 8(8), 250-255.

https://doi.org/10.29121/granthaa

layah.v8.i8.2020.1004

Received Date: 06 August 2020

Accepted Date: 31 August 2020

Keywords:

Foreign-Language Learning

Foreign Languages

Parents

Parent-Pupil Relationship

Motivation

Foreign-Language Teacher

\section{ABSTRACT}

Family is the social institution where a child is born, develops cognitively, socially and empathically, and which contributes to the child finding his/her place in the society of the future. Family helps a child form, learn, understand and develop basic aspects of his/her conduct out in the world until the he/she is introduced to the first education institution in his/her life, namely kindergarten. A pupil's success and efficiency take shape only if the relationship between school and family is very solid. If parents are involved in school and after-school activities, then they can even support foreign-language learning by donating teaching materials, textbooks, storybooks, games in foreign languages, puppets, etc. to the school library. They can work together with foreign-language teachers to organise field trips, camps, programmes, workshops, exchange courses abroad. Parents' involvement in school activities is a necessity for both the present and the future. Our article presents a survey of 290 pupils and 51 parents regarding the latter's views on studying foreign languages, which is promoted as part of current public and private educational offers.

\section{INTRODUCTION}

Views on the complex cognitive and emotional development required by today's society are capitalised on by the public and private educational system by promoting the European Union's principles regarding the learning of a foreign language at an early age.

Even though primary-school teachers claim that the age of 6 is less suitable for learning foreign languages, as a child that age is not familiar with the alphabet of his/her mother tongue, foreign-language teachers know that, by employing the appropriate strategies, methods, techniques and procedures, while also bearing in mind the process of developing the child's mother tongue, pupils can learn foreign languages starting at any age and do it at their own pace. Just as the methodics and didactics of the child's mother tongue promote activities based on communication, symbols, images, objects, so can a foreign-language teacher apply such methods for the efficient teaching of foreign languages.

Starting to learn a foreign language early represents a remarkable attempt for some parents, while, for others, it constitutes an unsuppressable fear. Some parents wish their children to start learning a foreign language early on due to it being necessary in the future, while others are sceptical, seeing foreign languages as a hindrance to their

(C) 2020 The Author(s). This is an open access article distributed under the terms of the Creative Commons Attribution License, which permits unrestricted use, distribution, and reproduction in any medium, provided the original author and source are credited. 
child's complex development, as they allegedly make it harder for the child to learn the basics of his/her mother tongue.

The desire to learn a foreign language requires scrupulous examination, which is why the parent is going to have to go through several questions in order to overcome his/her fears.

- To what extent does my desire as a parent match that of my child?

- How motivated is my child to learn a foreign language?

- What is the extent of my correct involvement in my child's education with respect to learning foreign languages?

\section{MATERIALS AND METHODS}

By ensuring the confidentiality of names, the questionnaire-based research method was convenient and enabled us to obtain honest answers.

Through our research, we managed to document the views of 290 pupils and 51 parents on children learning foreign languages in school. Our ideas were centred on the efficiency of didactic competences as compared to pupils' and parents' expectations and on parents' and pupils' attitudes towards learning foreign languages.

Thus, the questions we set out to answer via our research are the following:

- Which foreign languages do parents seek for our pupils?

- What is the children's knowledge level in the foreign language at the time of surveying the parents?

- Which are the factors motivating our pupils to learn foreign languages?

- What requirements do they have as to the consolidation of their knowledge of foreign languages?

- What were the parents' reasons for choosing their preferred options for the previous question?

\section{DISSCUSION AND RESULTS}

According to our research, parents and pupils are open to the learning of foreign languages thanks to permanent access to information in foreign languages through mass-media or the internet, but especially due to the offers provided by public and private education institutions which promote the learning of two or more Western or Eastern foreign languages.

As parents wish for their children's social and financial status to improve in adulthood, they encourage their children to learn at least two foreign languages.

Learning one foreign language is an attempt, while learning two becomes a challenge. Even though English remains one of the most sought-after foreign languages to learn due to currently available digital instruments, websites and online games, Table and Figure no. 1 also show us the language combinations which are the most desired by parents for their children: German-English, English-French, German-English-French.

These combinations of two or three foreign languages imply multiple controversies. As far as the pupils are concerned, each of them feels that the language he/she prefers (for various reasons) is easier. Among the reasons governing their preferences we can find: the sonority of the language, the similarity of the foreign language to the child's mother tongue or to another favoured foreign language. It may also be that the manner in which the child perceives a foreign language has been influenced by the opinions of the parents.

Our experience has revealed the following types of parents:

- those who encourage their children to learn at least one foreign language, leaving the choice of language to the children;

- those who force their children to learn English because German is difficult;

- those who force their children to learn Chinese/Japanese/Korean or German/Dutch/Swedish because these are difficult, yet sough-after foreign languages;

- those who force their children to learn French because it is the language spoken in their family, yet do not exclude the other foreign languages taught in school;

- those who have their children learn Italian or German with a private tutor, as such languages are useful later on for admission into a (high) school where they are studied at mother-tongue level;

- those who force their children to learn German because one of the parents is away in Germany working at a German company; 
- those who force their children to learn German because it is a language which one of the parents had the chance to learn as a child, but did not.

Table 1: The languages studied by the children of the surveyed parents

\begin{tabular}{|c|c|}
\hline Foreign languages studied by the children & $\%$ \\
\hline English & 14.9 \\
\hline French & 2.1 \\
\hline German-English tandem & 23.4 \\
\hline English-French tandem & 48.9 \\
\hline German-English-French tandem & 8.5 \\
\hline English-Spanish tandem & 2.1 \\
\hline
\end{tabular}

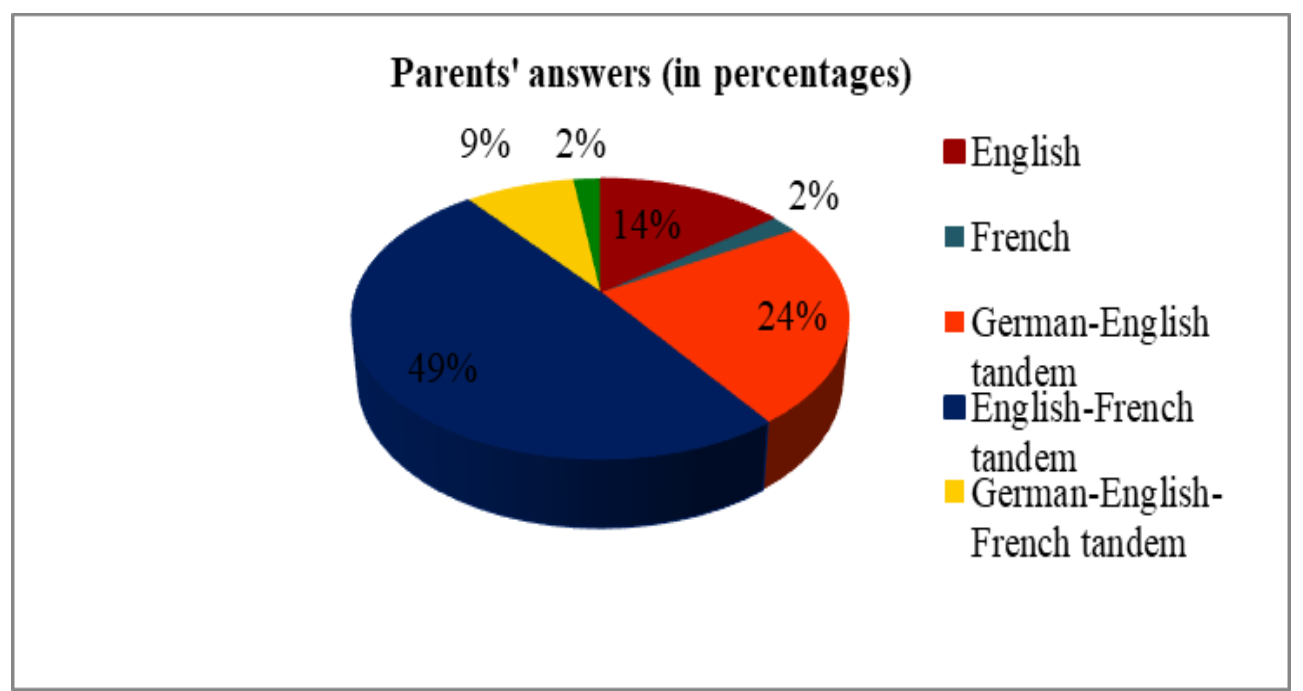

Figure 1: The languages studied by the children of the surveyed parents

Such opinions and many more can apply to other foreign languages as well. The ideas above show that parents' desires are influenced both by the usefulness of the foreign language being studied and by their own lack of access to a certain foreign language during their school years. However, the question is: to what extent are parents' views important?

According to the pupils surveyed, the motivation for learning a foreign language stems from the external factors they are exposed to daily during their years in school. Table and Figure no. 2 show the motivational factors perceived by pupils learning foreign languages:

Table 2: Motivational factors perceived by pupils learning foreign languages

\begin{tabular}{|c|c|}
\hline Motivational factors & $\%$ \\
\hline school teacher & 32.2 \\
\hline parents & 39.2 \\
\hline classmates & 2.4 \\
\hline school teacher and parents & 17.4 \\
\hline anyone & 0.6 \\
\hline private tutor & 16.1 \\
\hline
\end{tabular}

It only takes one glance to see what pupils think. Parents (39.2\%) have the greatest capacity to influence children, which is a positive aspect that reveals their involvement in children's education. Still according to pupils, the schoolteacher $(32.2 \%)$ is the second most influential person for them, while some pupils have difficulty deciding whether the greater influence over their decisions belong to the parents or the teacher. The opinions of other pupils point to their private tutor $(16.1 \%)$ and to their classmates $(2.4 \%)$, while $0.6 \%$ of the pupils rely on any motivational factor. 


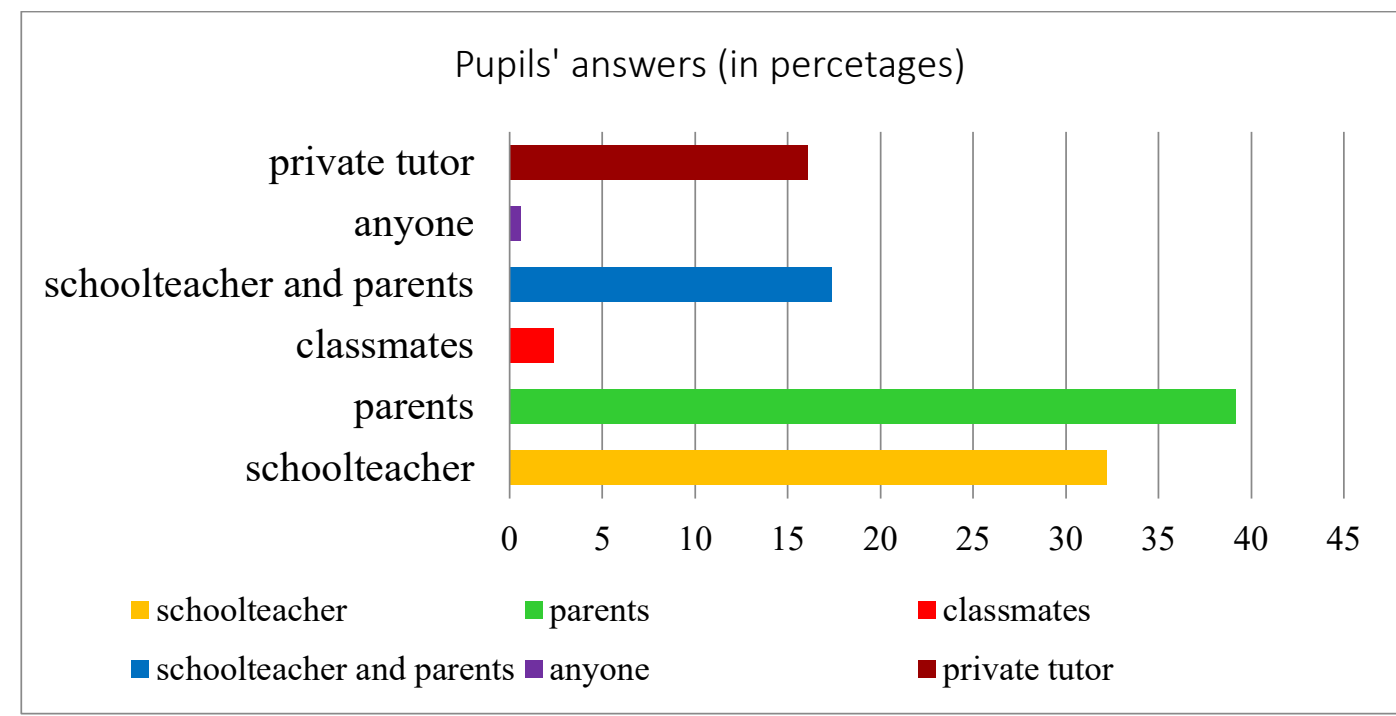

Figure 2: Motivational factors perceived by pupils learning foreign languages

As far as the actual learning of a foreign language is concerned, the pupils' level of knowledge does not constitute a reason for worry for some parents; on the contrary, they keep supporting the teaching of foreign languages (see Table and Figure no. 3). Why is that?

Table 3: The language level of the children of the surveyed parents

\begin{tabular}{|c|c|c|c|c|c|}
\hline \multirow[t]{2}{*}{ Foreign language } & \multicolumn{4}{|c|}{ Level (\%) } & \\
\hline & A1 & $\mathrm{A} 2$ & B1 & B2 & None \\
\hline German & 47.8 & 8.7 & 21.7 & 21.7 & \\
\hline English & 34.1 & 19.5 & 12.2 & 9.8 & 24.4 \\
\hline French & 40 & 28 & 16 & 8 & 8 \\
\hline Italian & & & & & 100 \\
\hline Spanish & 100 & & & & \\
\hline
\end{tabular}

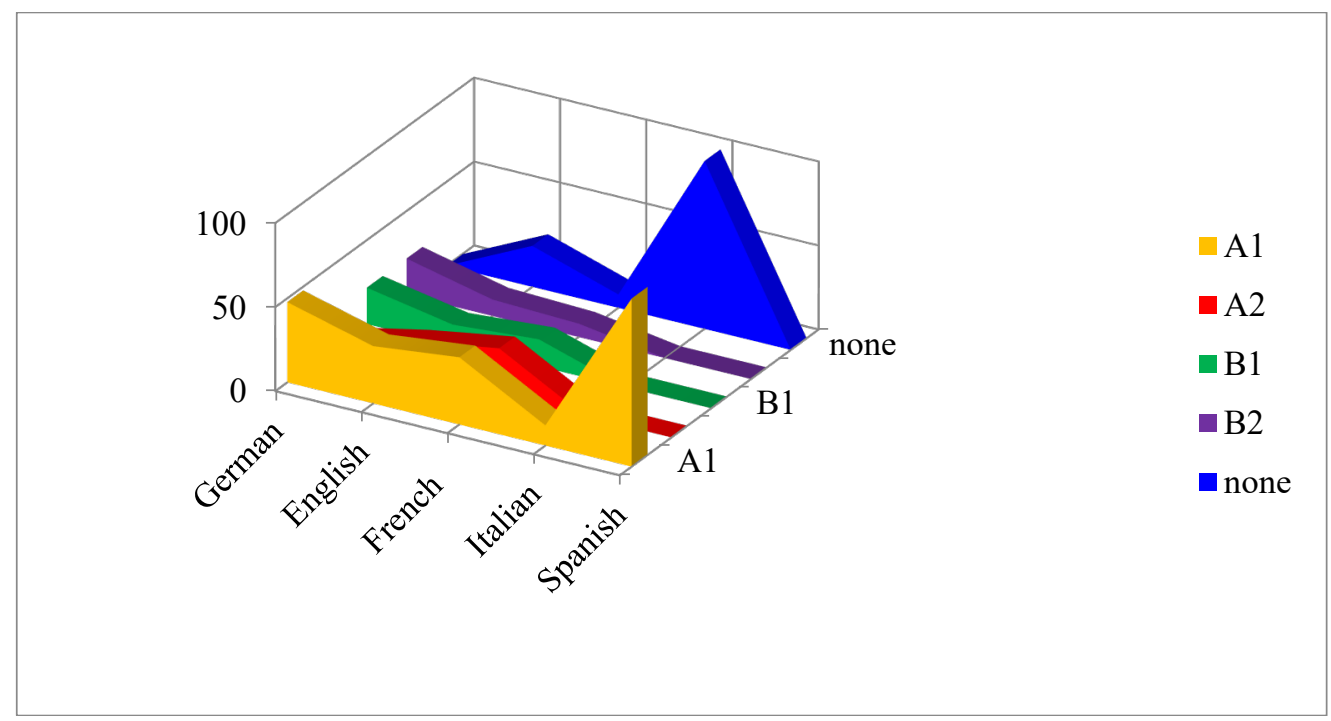

Figure 3: The language level of the children of the surveyed parents

Parents are aware that, thanks to the basic knowledge (A1) acquired, children will be able to independently acquire the basic knowledge for each level in time and through constant practice. Level A1 proves how important it is for a pupil to start learning a foreign language irrespective of his/her age, while also revealing parents' wishes as to their children's stage of development on the social ladder. 
Parents' appreciation for learning foreign languages, consolidating the knowledge taught and especially advancing from one level to another is also highlighted in Table and Figure no. 4 illustrating the reasons why parents opt for additional classes (either free ones organised at school or paid ones at home) for their children.

Table 4: Reasons for supporting after-school foreign-language classes

\begin{tabular}{|c|c|}
\hline Reasons & $\%$ \\
\hline Clarifications provided by the teacher for notions which were not understood during regular classes & 66.7 \\
\hline Doing the homework for foreign-language classes & 2.1 \\
\hline Reading time in a foreign language for children (at the school library / in the classroom) & 16.7 \\
\hline I do not know & 2.1 \\
\hline I do not agree & 12.5 \\
\hline
\end{tabular}

\section{Parents' answers (in percentages)}

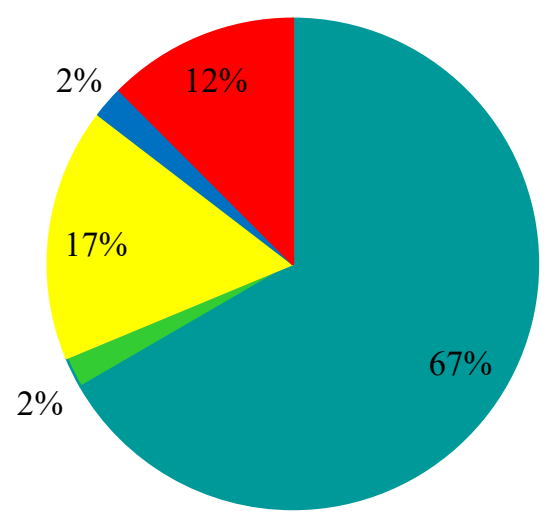

Clarifications provided by the teacher for notions which were not understood during regular classes $\square$ Doing the homework for foreignlanguage classes

Reading time in a foreign language for children (at the school library / in the classroom)

I do not know

I do not agree

Figure 4: Reasons for supporting after-school foreign-language classes

Parents are of the opinion that two hours of foreign languages per week at school are not sufficient for children to learn them. That is why, for $66.7 \%$ of parents, additional classes are meant to give teachers the opportunity to clarify the notions taught during regular classes, while $16.7 \%$ wish for their children to have special classes for reading in foreign languages at the school library. $12.5 \%$ of the parents do not want additional classes, as they find the children's schedule much too busy.

However, parents opt for additional foreign-language classes for pupils for a set of well-defined purposes (see Figure no. 5), but also in order to facilitate foreign-language learning through diverse teaching, learning and evaluation styles.

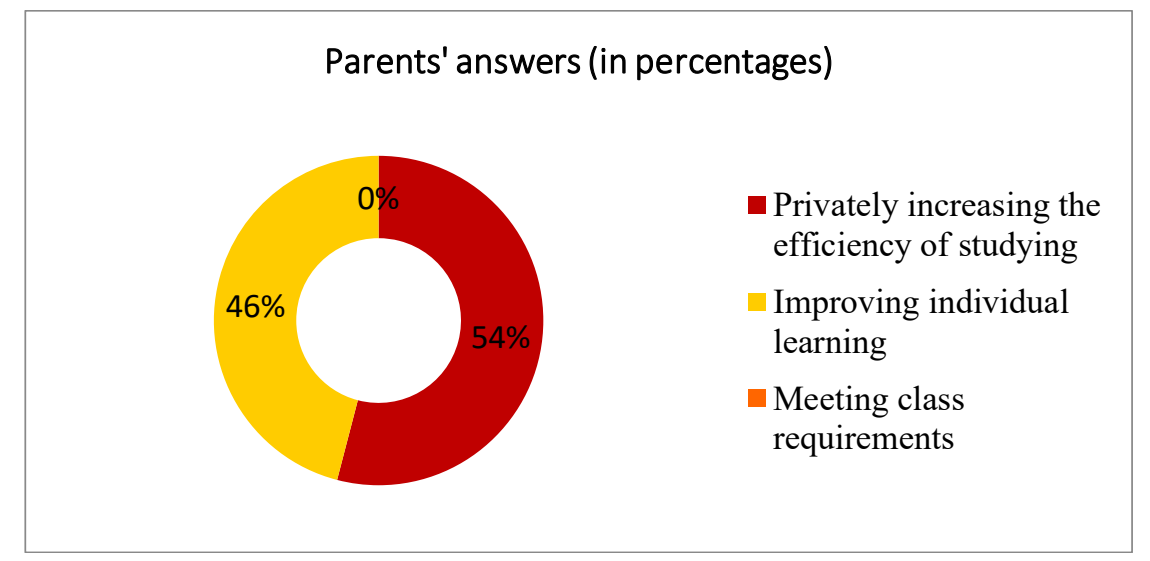

Figure 5: Reasons why parents have opted for additional foreign-language classes 


\section{CONCLUSION}

Our research has revealed that one thing is certain: parents are the motivational and decisional factors when it comes to children's education, as they have a tendency to influence the children's future by recommending the fields of study they should go into as adults in order to have a financially secure and stable work place.

As for the learning of a foreign language, as parents, people aim for their children not only to learn a foreign language, but also to perfect their knowledge in order to attain a higher social status both inside and outside the school. At the same time, some parents determine their children to learn a foreign language to probably compensate for their own lack of opportunity to learn one as children.

As teachers are aware of the importance of parents' constant participation in pupils' education, they will encourage them to get involved, while helping them understand the efficiency of a parent's consistent emotional presence in the teacher-pupil-parent relationship and in the teaching, learning and evaluation processes during a child's school years.

That is why we recommend that even uneasy parents, who regard learning foreign languages at an early age with scepticism, should be encouraged and not judged by teachers. Each parent knows the limits of his/her child, as well as his/her own limits depending on available opportunities.

What is certain is that foreign languages contribute to the child's social and personal shaping and development, as they give him/her confidence in his/her intellectual and emotional skills. That is why, by virtue of his/her competences, a teacher is obliged to develop the ability to advise and help parents make relevant decisions for any context, as well as the ability to manage direct and indirect conflicts between parents and pupils, thus contributing to the honing of parents' wishes - for their role is most necessary in a child's education - and to outlining a path for undecided pupils.

\section{SOURCES OF FUNDING}

This research received no specific grant from any funding agency in the public, commercial, or not-for-profit sectors.

\section{CONFLICT OF INTEREST}

The author have declared that no competing interests exist.

\section{ACKNOWLEDGMENT}

None.

\section{REFERENCES}

[1] Dumitriu, G. (1998). Comunicare și învățare [Communication and Learning]. Published by Editura Didactică și Pedagogică. 